\title{
Model Penyusunan Kualitas Tempat Tumbuh Eucalyptus urophylla Pada Hutan Tanaman
}

\author{
Marulam MT Simarmata \\ Dosen Fakultas Pertanian USI \\ E-mail : simarmatamarulam@yahoo.com
}

\begin{abstract}
Abstrak
Pembagunan bidang kehutanan, khususnya hutan tanaman idustri diharapkan dapat menghasilkan tegakan dengan produktivitas (riap) yang tinggi dan mutu kayu yang memenuhi persyaratan bahan baku industri kehutanan. Kegiatan pengelolaan hutan lestari memerlukan rencana jangka panjang dengan bantuan perangkat-perangkat perancanaan yang tepat. Peninggi dapat digunakan untuk menentukan kelas kualitas tapak suatu tegakan hutan, karena sampai batas kerapatan tegakan tertentu tinggi pohon tidak terpengaruh oleh kerapatan tegakan.

Tujaan penilitian ini adalah untuk membuat model penyusunan kualitas tempat tumbuh hutan tanaman Eucalyptus urophylla di hutan tanaman industri.

Model indeks tempat tumbuh didasarkan pada hubungan matematis antar peninggi dan umur tegakan, dengan menggunakan model yang telah diuji pada jenis lain. Model yang terbaik adalah memiliki nilai $R^{2}$ cukup tinggi, serta nilai SA yang lebih kecil dari 1 dan lebih besar dari -1, serta nilai SR yang lebih kecil dari $1 \%$.

Model penduga untuk menerangkan hubungan antara umur dengan peninggi tegakan Eucalyptus urophylla adalah model Averi yakni Log $H=\beta_{0}+\beta_{1} A^{-1}$ dengan nilai $R^{2}=92,6$.

Dengan menggunakan umur indeks 8 tahun, maka persamaan indeks tempat tumbuh yang terbentuk adalah Log $S I=\log H-1,13\left(A^{-1}-8^{-1}\right)$. Hasil pendugaan menunjukkan bahwa indeks tempat tumbuh dari petak-petak ukur mempunyai variasi antara 20,65 - 26,40. Berdasarka model yang dihasilkan, kualitas tempat tumbuh tanaman dilokasi dapat dikelompokkan menjadi 4 bonita. Model yang dihasilkan hanya efektif dipergunakan untuk menduga bonita jenis Eucalyptus urophylla dari umur 1 sampai 7 tahun.
\end{abstract}

Kata kunci : Model, Kualitas Tapak, Eucalyptus

\section{PENDAHULUAN}

Pembagunan bidang kehutanan, khususnya hutan tanaman idustri diharapkan dapat menghasilkan tegakan dengan produktivitas (riap) yang tinggi dan mutu kayu yang memenuhi persyaratan bahan baku industri kehutanan. Oleh karena itu penerapan ke- giatan silvikultur intensif dan pengelolaan hutan tanaman yang profesional menjadi suatu keharusan.

Mengingat kualitas tempat tumbuh (bonita) mempengaruhi pertumbuhan tanaman maka upaya pemilihan tempat tumbuh yang cocok merupakan hal yang sangat penting. Setiap tegakan mempu- 
nyai karakteristik pertumbuhan yang berbeda tergantung pada jenis, tipe tapak, perlakuan silvikultur dan faktor lingkugan lainnya. Hal ini menyebabkan tabel tegakan merupakan rangkuman informasi kuantitatif pertumbuhan dan hasil tegakan seperti perkembangan diameter, luas bidang dasar, dan isi tegakan suatu hutan tanaman yang tumbuh pada kualitas tempat tumbuh (bonita) tertentu bersifat spesifik untuk jenis dan lokasi tertentu.

Kegiatan pengelolaan hutan lestari memerlukan rencana jangka panjang dengan bantuan perangkat-perangkat perancanaan yang tepat. Salah satu perangkat perencanaan yang dibutuhkan adalah perangkat pendugaan kualitas tempat tumbuh (bonita). Bonita bersifat spesifik untuk tiap jenis karena setiap jenis menuntut persyaratan tempat tumbuh dan memiliki prilaku pertumbuhan yang berbeda. Oleh sebab itu setiap jenis memerlukan perangkat pembonitaan tersendiri yang berbeda dengan jenis lainnya. Secara tidak langsung kualitas tempat tumbuh dapat diduga melalui perhitungan indeks tinggi pohon (peninggi). Peninggi dapat digunakan untuk menentukan kelas kualitas tapak suatu tegakan hutan, karena sampai batas kerapatan tegakan tertentu tinggi pohon tidak terpengaruh oleh kerapatan tegakan.

Tujaan penilitian ini adalah untuk membuat model penyusunan kualitas tempat tumbuh hutan tanaman Eucalyptus urophylla di hutan tanaman industri PT. Toba Pulp Lestari Sektor Aek Nauli Kecamatan Girsang Sipagan Bolon Kabupaten Simalugun.

\section{METODE PENELITIAN}

Penelitian ini dilaksanakan di areal hutan tanaman Eucalyptus PT. Toba Pulp Lestari sektor Aek Nauli Kecamatan Girsang Sipanganbolon. Menurut areal wilayah administrasi sektor Aek Nauli terletak di daerah Pemerintah Kabupaten Simalungun dan Kabupaten Karo. Areal HPHTI PT. Toba Pulp Lestari sektor Aek Nauli mempunyai luas 22.533 ha. Lokasi penelitian memiliki topograpi datar dan bergelombang dengan ke- 
lereng $0-25 \%$ dengan ketinggian tempat sekitar $1.200 \mathrm{mdpl}$.

Tipe tanah di wilayah ini sebagian besar bertipe tanah kompleks yaitu Podsolik Coklat, Podsolik Coklat Kuning dan Podsolik Coklat Kelabu yang terbentuk dari bahan induk berupa batuan beku dan bantuan metamorf yang $\mathrm{u}$ mumnya bersifat asam.

Menurut klasifikasi iklim oleh Schmidt dan Fergusson (1951) secara umum areal HTI PT. Toba Pupl Lestari termasuk daerah beriklim sangat basah (tipe iklim A) dengan curah hujan rata-rata tahunan 1.917,7 mm

Bahan yang digunakan dalam penelitian ini adalah tegakan tanaman jenis Eucalyptus pada berbagai umur tanaman (1-7 tahun).

Sedangkan alat yang digunakan adalah haga hypsometer, phiband, parang, tali, dan alat tulis. Pengumpula data dilakukan dengan meembuat petak ukur semi permanen berukuran $20 \times 20 \mathrm{~m}$ sebanyak 10 buah untuk setiap umur tanaman dan lokasi petak ukur diletakkan secara acak yang dilihat secara makro memiliki kondisi tempat tumbuh yang berbeda.

Semua pohon yang berada di dalam petak ukur diukur diameter dan tingginya. Untuk penyusunan model indeks tempat tumbuh dipilih sebanyak 4 pohon tertingi pada petak ukur sebagai peninggi. Peninggi adalah rata-rata tinggi dari pohon-pohon tertinggi pada petak ukur yang bersangkutan. Untuk mengukur tinggi pohon digunakan alat ukur tinggi yaitu SRB (spigel relascope bieterlich) dengan mengambil jarak tembak 20 m dari pohon.

Model indeks tempat tumbuh didasarkan pada hubungan matematis antar peninggi dan umur tegakan, dengan menggunakan model yang telah diuji pada jenis lain (Purpasari dan Achmad, 2000, ; Aswandi dan Ali, 2003) sebagai berikut :

$$
\log H=\beta_{0}+\beta_{1} A^{-1}
$$

Jika ukur (A) setara dengan umur indeks $\left(A_{i}\right)$, maka peninggi $(H)$ setara dengan SI (site indeks), yakni :

$$
\log S I=\beta_{0}+\beta_{1} A_{i}^{-1}
$$


Dari persamaan, maka subsitusinya :

$$
\begin{aligned}
\log H & =\log S I-\beta_{1} A_{i}^{-1}+\beta_{1} A^{-1}+ \\
& =\log S I+\beta_{1}\left(A^{-1}-A_{i}^{-1}\right)
\end{aligned}
$$

Sehingga perhitungan SI akan memperoleh rumus :

$$
\begin{aligned}
& \log S I=\log H-\beta_{1}\left(A^{-1}-A_{i}^{-1}\right) \\
& H=\beta_{0}+\beta_{1}\left(\ln A_{1}\right)^{k}(\text { Alder, } 1980)
\end{aligned}
$$

Jika umur (A) setara dengan umur indeks $\left(A_{i}\right)$, maka peninggi $(H)$ setara dengan SI, yakni :

$$
\mathrm{SI}=\beta_{0}+\beta_{1}\left(\ln \mathrm{A}_{1}\right)^{\mathrm{k}}
$$

Selanjutnya hubungan antara indeks tempat tumbuh dengan peninggi adalah :

$$
\begin{aligned}
& \mathrm{SI}=\left(\mathrm{H}-\beta_{0}\right)\left(\ln \mathrm{A}_{1} / \ln \mathrm{A}\right)^{\mathrm{k}}+\beta_{0} \\
& \text { dimana : } \\
& \mathrm{H}=\text { peninggi tegakan }(\mathrm{m}) \\
& \mathrm{SI}=\text { site indeks } \\
& \mathrm{A}=\text { umur tegakan } \\
& \beta_{0}=\text { intersep persamaan } \\
& \beta_{1}=\text { koefisien regresi } \\
& \mathrm{k}=\text { tetapan }
\end{aligned}
$$

Analisa yang digunakan untuk mengetahui nilai-nilai tersebut dilakukan dengan analisa regresi non linear dengan metode kuadrat terkecil (least square methode). Model-model penduga yang telah terbentuk diuji lebih lanjut melalui sidik ragam regresi dan perhitungan koefisien determinasinya $\left(\mathrm{R}^{2}\right)$.

Model terbaik dipilih berdasarkan kriteria nilai koefisien determinasi $\left(\mathrm{R}^{2}\right)$, nilai simpangan agregat (SA) dan nilai simpangan rata-rata (SR).

$$
\mathrm{SA}=\frac{\Sigma \mathrm{Ha}-\Sigma \mathrm{Ht}}{\Sigma \mathrm{Ht}} \times 100 \%
$$

$$
\mathrm{SR}=\frac{\Sigma \frac{\mathrm{Ha}-\mathrm{Ht}}{\mathrm{Ht}}}{\mathrm{N}} \times 100 \%
$$

dimana :

$\mathrm{Ha}=$ nilai aktual hasil pengukuran

$\mathrm{Ht}=$ nilai dugaan dari model

$\mathrm{N}=$ jumlah contoh

Model yang terbaik adalah memiliki nilai $\mathrm{R}^{2}$ cukup tinggi, serta nilai SA yang lebih kecil dari 1 dan lebih besar dari -1 , serta nilai SR yang lebih kecil dari 1\% (Bruce, 1920 dalam Spurr, 1952)

\section{HASIL DAN PEMBAHASAN}

\section{a. Model Perkembagan Pe- ninggi Eucalyptus Uro- phylla}

Data hasil penilitian yang didapat dari lapangan setelah dianalisis dengan menggunakan regresi non-linear pada program 
Minitab 11, diperoleh model perkembangan peninggi beserta sidik ragam regresinya sebagai berikut :
1. $\log H=\beta_{0}+\beta_{1} A^{-1}$

(Avery,1994)

$\log H=1,56-1,13 A^{-1}$

Tabel 1. Tabel Analisa Sidik Ragam Regresi Persamaan (1)

\begin{tabular}{|l|c|c|c|c|c|}
\hline Sumber & $\begin{array}{c}\text { Derajat } \\
\text { Bebas }\end{array}$ & $\begin{array}{c}\text { Jumlah } \\
\text { Kuadrat }\end{array}$ & $\begin{array}{c}\text { Kuadrat } \\
\text { Tegah }\end{array}$ & F. Hitung & P \\
\hline Regresi & 1 & 6,9848 & 6,9848 & 847,94 & 0,000 \\
\hline Sisaan & 68 & 0,5601 & 0,0082 & & \\
\hline Total & 69 & 7,5449 & & & \\
\hline
\end{tabular}

Dilihat dari tabel diatas bahwa model Avery memiliki nilai $\mathrm{F}$ Hitung Regresi 847,94 kuadrat tengah 6,9848, jumlah kuadrat 6,9848 dan nilai PRESS yaitu prediksi pendugaan kesalahan sebesar 0 . Artinya nilai koefisien regresi dari model penduga tersebut dapat diandalkan untuk meramalkan besarnya peninggi pohon.
(Alder, 1980)

$$
H=2,94+21(\ln A)^{0,192}
$$

Tabel 2. Tabel Analisa Sidik Ragam Regresi Persamaan (2)

\begin{tabular}{|l|c|c|c|c|c|}
\hline Sumber & $\begin{array}{c}\text { Derajat } \\
\text { Bebas }\end{array}$ & $\begin{array}{c}\text { Jumlah } \\
\text { Kuadrat }\end{array}$ & $\begin{array}{c}\text { Kuadrat } \\
\text { Tegah }\end{array}$ & F. Hitung & P \\
\hline Regresi & 1 & 3290,6 & 3290,6 & 107,13 & 0,000 \\
\hline Stsaan & 68 & 2088,6 & 30,7 & & \\
\hline Total & 69 & 5779,3 & & & \\
\hline
\end{tabular}

Dilihat dari tabel diatas bahwa model tabel Avery memiliki nilai F Hitung regresi 107,13, kua- drat tenggah 3290,6, jumlah kuadrat 3290,6 dan nilai PRESS yaitu prediksi pendugaan kesala- 
han sebesar 0. Artinya nilai koefisien regresi dari model penduga tersebut dapat diandalkan namun dibandingkan model pertama model kedua ini mempunyai nilai $\mathrm{F}$ Hitung yang lebih kecil.

b. Pemelihan Model Terbaik
Model penduga indeks tempat tumbuh terbaik dipilih berdasarkan nilai koefisien determinasi $\left(\mathrm{R}^{2}\right)$, simpangan Agregat (SA) dan simpangan rata-rata (SR). Besarnya nilai masing-masing kriteria tersebut untuk kedua model yang diuji adalah :

Tabel 3. Nilai-nilai F hitung, R², SA, SR, Dan PRESS Kedua Model yang Diuji.

\begin{tabular}{|l|l|l|l|l|l|l|l|l|}
\hline No & Persamaan/Model & $\mathbf{R}^{2}$ & S & MSE & Fhit & SR & SA & PRESS \\
\hline 1 & $\begin{array}{l}\text { Log H }=1,56-1,13^{1 *} \\
\text { (Avery) }\end{array}$ & 92,6 & 0,09076 & 0,0082 & 847,94 & 0,397 & 0,3353 & 0,58770 \\
\hline 2 & $\begin{array}{l}\text { H=-,94+21,6 }(\ln A)^{0,19} \\
\text { (Alder) }\end{array}$ & 61,2 & 5,542 & 30,7 & 107,13 & 0,487 & 0,3939 & 2167,04 \\
\hline
\end{tabular}

Ket : * model terbaik

Tabel 4. Perkembangan Peninggi Eucalyptus urophylla pada Berbagai Bonita Site Indeks Tertinggi 26,39 dan Terendah 20,65 Menjadi dari 20,65 26,40

\begin{tabular}{|c|c|c|c|c|}
\hline Umur & $\begin{array}{c}\text { Bonita I } \\
(\text { SI 21,36) }\end{array}$ & $\begin{array}{c}\text { Bonita II } \\
(\text { SI 22,80) }\end{array}$ & $\begin{array}{c}\text { Bonita III } \\
\text { (SI 24,24) }\end{array}$ & $\begin{array}{c}\text { Bonita IV } \\
\text { (SI 25,68) }\end{array}$ \\
\hline 1 & $0,210-0,220$ & $0,221-0,230$ & $0,231-0,240$ & $0,241-0,250$ \\
\hline 2 & $1,930-2,040$ & $2,041-2,150$ & $2,151-2,260$ & $2,261-2,370$ \\
\hline 3 & $5,810-6,312$ & $6,313-6,815$ & $6,816-7,317$ & $7,318-7,820$ \\
\hline 4 & $11,77-12,75$ & $12,76-13,73$ & $13,74-14,71$ & $14,72-15,70$ \\
\hline 5 & $16,31-17,51$ & $17,57-18,82$ & $18,83-20,08$ & $20,09-21,34$ \\
\hline 6 & $19,45-20,58$ & $20,59-21,71$ & $21,72-22,84$ & $22,85-23,98$ \\
\hline 7 & $20,65-22,08$ & $22,09-23,52$ & $23,53-24,96$ & $24,97-26,40$ \\
\hline
\end{tabular}


Dilihat dari Tabel 3, berdasarkan kriteria keterhandalan model yang di tetapkan oleh Bruce (1920) dalam Spurr (1952) sebenarnya kedua model tersebut memenuhi persyaratan untuk digunakan sebagai penduga indeks tempat tumbuh. Akan tetapi berdasarkan kriteria model terbaik, model Avery - $\log H=1,56-1,13 \mathrm{~A}^{-1}$ memiliki kelebihan dalam menerangkan hubungan antara A (umur) dah $\mathrm{H}$ (peninggi) karena memiliki nilai $\mathrm{F}$ hitung dan $\mathrm{R}^{2}$ yang lebih besar serta nilai SR, S, SA, MSE Dan PRESS, yang lebih kecil dibanding model Alder.

Pertimbangan lainnya dalam pemilihan model adalah kesederhanaan dan kepraktisan model. Nilai koefisien determinasi yang sangat besar yaitu 92,6\% berarti, bahwa 92,6\% variasi faktor peninggi tegakan dapat diterangkan oleh umur tegakan menurut model regresi tersebut.

Pengujian ketelitian model indeks tempat tumbuh yang dihasilkan dari penelitian ini dilakukan dengan menghitung simpangan agregat (SA) dan rataan persentase simpangan (SR).
Hasil perhitungan menunjukkan bahwa nilai SA dan SR model indeks tempat tumbuh tersebut berturut-turut $\quad 0,3353 \%$ dan 0,397 \%. Dalam pembentukan persamaan indeks tempat tumbuh tegakan, terlebih dahulu ditetapkan umur indeks, yaitu umur yang akan digunakan sebagai penentu indeks tempat tumbuh tegakan hutan tanaman Eucalyptus urophylla untuk keperluan pulp, khususnya dilokasi penelitian direncanakan ditebang sekitar umur 8 tahun. Jadi umur indeks ditetapkan umur 8 tahun.

Indeks tempat tumbuh (SI) adalah besaran peninggi tegakan pada umur indeks, sehingga dengan umur indeks 8 tahun dan dengan menggunakan model Avery yang terpilih sebagai model terbaik diperoleh model indeks tempat tumbuh hutan tanaman Eucalyptus urophylla seperti tertulis dibawah ini :

\section{$\log S I=\log H-1,13\left(A^{-1}-8^{-1}\right)$}

Hasil pendugaan menunjukkan bahwa indeks tempat tumbuh dari petak-petak ukur mempunyai variasi antara 20,65 26,40 . Oleh sebab itu grafik bonita 
Eucalyptus urophylla disusun dengan besaran indeks tempat tumbuh mulai dari 21,36 - 25,68 dengan selang 1 meter.

Hasil pegujian menunjukkan bahwa terdapat perbedaan site indeks pada setiap kelas umur yang juga dapat ditunjukkan oleh grafik dibawah ini. Terlihat bahwa respon pertumbuhan Eucalyptus urophylla terhadap tempat-tempat tumbuh sebagai media tumbuhnya menunjukkan hubugan yang positif antara kualitas tempat tumbuhnya dengan tinggi yang dicapai sangat baik. Gambar 1 berikut ini akan memperlihatkan Kurva indeks.

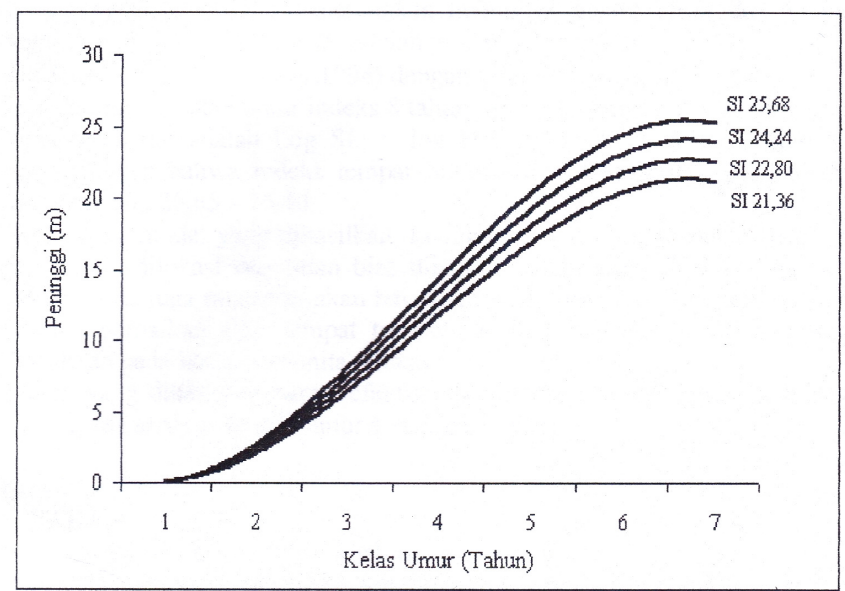

Secara umum terlihat adanya indikasi bahwa kualitas tempat tumbuh dilokasi penilitian relatif tinggi yang ditunjukkan oleh kelerengan kurva yang cenderung sigmoid. Tempat tumbuh yang memiliki kualitas yang tinggi biasanya memiliki bentuk hubungan peninggi dengan umur yang selaras dengan bentuk pertumbuhan pohon itu sendiri, sebaliknya kulitas tapak yang rendah akan cenderung membentuk kurva hubungan umur dan peninggi yang landai.

Dari data diatas maka jelaslah bahwa tinggi pohon tidak dipengaruhi oleh kerapatan tegakan, karena pertumbuhan tanaman lebih dulu membentuk tinggi kemdian memperbesar diameter, dan pada pertumbuhan awal tanaman cenderung berkompetisi terhadap tanaman yang lainnya akan kebutuhan unsur-unsur harta 
dalam tanah, air dan cahaya. Sejalan dengan kompetisi tersebut pertambahan tinggi penuh pohon akan bertambah sampai pada tinggi dan umur maksimal tercapai.

\section{KESIMPULAN}

1. Model penduga untuk menerangkan hubungan antara $\mathrm{u}-$ mur dengan peninggi tegakan Eucalyptus urophylla adalah model Averi yakni Log $\mathrm{H}=\beta_{0}+\beta_{1} \mathrm{~A}^{-1}$ (Avery,1994) dengan nilai $\mathrm{R}^{2}=92,6$.

2. Dengan menggunakan umur indeks 8 tahun, maka persamaan indeks tempat tumbuh yang terbentuk adalah Log SI $=\log \mathrm{H}-1,13\left(\mathrm{~A}^{-1}-8^{-1}\right)$. Hasil pendugaan menunjukkan bahwa indeks tempat tumbuh dari petak-petak ukur mempunyai variasi antara 20,65 - 26,40.

3. Berdasarka model yang dihasilkan, kualitas tempat tumbuh tanaman dilokasi dapat dikelompokkan menjadi 4 bonita. Sekaligus kelas bonita juga mencerminkan banyaknya kelas produktivitas sehingga prioritas upanya perbaikan sifat tempat dengan tindakan silvikultur sebaiknya diarahkan pada lahan berbonita rendah.

4. Model yang dihasilkan hanya efektif dipergunakan untuk menduga bonita jenis Eucalyptus urophylla dari umur 1 sampai 7 tahun.

\section{PUSTAKA}

Aswandi dan Cica Ali. 2003. Model Pertumbuhan dan Hasil Hutan Tanaman di Sumatera Bagian Utara

Baker F.S., Theodore W. Daniel, Jhon A. Helms. 1950. Prinsip-Prinsip Silvikultur. Terjemahan Universitas Gajah Mada Press.

Bickford, CA., F.S. Baker dan F. G.Wilson. 1957. Stocking, Normality and Measurement of Stand Density, for., 55:99-104.

Ford Robinson, F.C. (ed). 1971. Terminology of Forest Science, Technology Practice And Products, Soc. Am. Forester, Washington D.C. 
Jones. R,. 1969. Review and Comparison of Site Evaluation Methods, USDA Forest ser. Res. PAP.RM-51.

Khaerudin. 1999. Pembibitan Tanaman Hutan Tanaman Industri. Penebar Swadaya Cetakan 2. Jakarta.

Manan, S,. 1992. Silvikultur, Manual Kehutanan Depatermen Kehutanan Republik Indonesia. Jakarta. ,1976. Silvikultur, Priyok Pengembagan Perguruan Tinggi. Institut Pertanian Bogor.
Poerwidodo. 1990, Gatra Tanah Dalam Pembangunan Hutan Tanaman Indonesia Rajawali Press. Jakarta.

Puspasari, D. san B. Achmad. 2000. Model Penaksiran Tempat Tumbuh Hutan Tanaman Acacia Mangium. Buletin Penilitian Kehutanan Vol. 16 No 1. 72000.

Soedijianto, 1976. Bercocok Tanam. Tanah dan Kesuburan Tanah. C.V. Yasguna Jakarta.

Spurr, S.H. 1952. Forest Iventory. The Ronald Press Company. New York. 